\title{
Menggali Etika Pengacara dalam Alquran
}

\author{
Jefry Tarantang \\ IAIN Palangka Raya \\ jefrytarantang@gmail.com
}

\begin{abstract}
The advocates are the professions (officium nobile) who act law enforcers. The advocates as law enforcers guaranteed by the regulation no. 18 the year 2003 about the advocates are tied with the ethics. The ethics of Indonesian Advocates the year 2002 becomes the guidance for the advocates in performing their professions. However, those advocates who are Muslims, the ethics should be based on the values in the Alquran. The study is classified as explanatory, namely, explaining, strengthening, or examining a regulation related of the ethics of advocates. The results of the analysis concluded that Quran Surah Annisa [4]: 58,105, and 135 as the bases of the ethics of the advocates. The concepts of the ethics in these verses, are, trusteeship and fair, including good behaviors, honesty, responsible, professional, having the skill, having high integrity in performing professions as law enforcers constitutionally. The ethics of the advocates in the Alquran can be applied by protected the positive law in the form of the collaboration of the ethics based on the qur'anic values and the regulation no. 18 the year 2003 about the Advocates, and the Ethics of the Indonesian Advocates the year 2002.
\end{abstract}

Keywords: ethics, advocates, and Alqur

\section{A. Pendahuluan}

Salah satu profesi hukum yang memiliki kewajiban yang sangat penting dalam upaya penegakan supremasi hukum adalah advokat, yang menuntut adanya semangat perjuangan untuk terselenggaranya peradilan yang jujur, adil, dan memiliki kepastian hukum yang jelas dan terang bagi para pencari keadilan dalam menegakkan hukum, kebenaran, dan hak asasi manusia (HAM). Advokat adalah pekerjaan yang dikualifikasikan sebagai profesi sehingga dalam menjalankan profesi sebagai advokat terikat oleh adanya kode etik. Profesi advokat tidak terikat suatu jabatan (hierarki) yang secara instruktif mempengaruhi profesi tersebut dalam menjalankan pekerjaan yakni penegakan supremasi hukum.

Advokat dituntut profesional dalam menjalankan profesinya sehingga harus memiliki standar prosedur baku yang menjamin bahwa tidak akan melakukan penyimpangan, kesalahan atau kelalaian yang merugikan para 
pencari keadilan, melukai rasa keadilan masyarakat, mengingkari kebenaran hukum atau membohongi hati nurani sendiri, serta melanggar ketentuan peraturan perundang-undangan yang mengatur tugas profesinya. Dalam rangka memenuhi kualifikasi predikat profesional tersebut, advokat sebagai profesi hukum wajib memiliki etika profesi, yaitu standar profesionalisme dalam menjalankan tugas profesi berdasarkan legal skill dengan pedoman etika profesi untuk mewujudkan penegakan supremasi hukum yang berkeadilan.

Selama ini dalam menjalankan profesinya advokat berpedoman pada hasil legislasi falsafati dalam legalitas hukum positif (hasil pemikiran legislator pembuat peraturan perundang-andangan), sebagai etika advokat yaitu Undang-Undang Nomor 18 Tahun 2003 tentang Advokat, dan hasil pemikiran anggota asosiasi atau organisasi advokat yang tertuang dalam Kode Etik Advokat Indonesia (KEAI) Tahun 2002.

Aturan tersebut merupakan pedoman bagi seluruh advokat di Indonesia, namun bagi advokat yang beragama Islam, Alquran dan hadis merupakan pedoman hidup yang utama dan tertinggi di atas semua peraturan perundang-undangan. Alquran mengatur perilaku advokat bertujuan membentuk kepribadian advokat yang memiliki akhlak, etika, maupun moralitas yang mampu menciptakan keadilan sebagai substansi dari hukum.

Hal ini belum adanya kajian mendalam yang membahas etika advokat berdasarkan nilai-nilai yang terkandung dalam Alquran, dan menguji Undang-Undang Nomor 18 Tahun 2003 tentang Advokat, dan Kode Etik Advokat Indonesia (KEAI) Tahun 2002 apakah sudah sesuai dengan nilainilai yang terkandung dalam Alquran. Menjadi peluang untuk para penstudi hukum melakukan penelitian dan pengkajian hukum, khususnya dalam kerangka penelitian hukum Islam. Senyatanya nilai-nilai religius dalam Alquran belum konkret dipraktekan dan dihayati oleh advokat yang beragama Islam, sehingga 
penulis sebagai peneliti merasa berkepentingan untuk menggali makna dari kandungan Alquran yang memiliki nilai-nilai etika dalam sistem nilai pembentukan kepribadian (akhlak) advokat. Penelitian ini dilakukan penulis adalah sebagai upaya pembentukan etika advokat dalam membangun sistem penegakan supremasi hukum di Indonesia yang lebih baik.

Adapun tipe penelitian yang digunakan dalam penelitian ini bisa disebut penelitian eksplanatoris, yaitu menerangkan, memperkuat, atau menguji suatu ketentuan hukum terkait etika advokat. ${ }^{1}$

Penelitian ini disebut juga sebagai penelitian kepustakaan (library research), yaitu penelitian yang dilakukan melalui bahan-bahan pustaka atau literatur kepustakaan sebagai sumber tertulis. Lebih spesifik, jenis penelitian ini juga disebut penelitian hukum normatif ${ }^{2}$ dalam kerangka preskriptif hukum Islam. Data dikumpulkan dengan menggunakan teknik penelaahan terhadap referensi-referensi yang relevan dan berhubungan dengan permasalahan yang akan diteliti, khususnya menggali etika advokat dalam Alquran.

\section{B. Kajian Pustaka}

Sebagaimana telah diungkapkan pada kerangka teori di muka bahwa etika $^{3}$ adalah karakter, watak, kesusilaan. Etika sangat erat berkaitan dengan

\footnotetext{
${ }^{1}$ Bambang Waluyo, Penelitian Hukum dalam Praktek, ( Jakarta: Sinar Grafika, 2008), hal. 9.

2 Sudikno Mertokusumo, Penemuan Hukum, (Yogyakarta: Universitas Atma Jaya, 2010), hal.37.

${ }^{3}$ Shidarta, Moralitas Profesi Hukum Suatu Tawaran Kerangka Berpikir, Bandung: Refika Aditama, 2009, h. 4-6, berpendapat bahwa, secara umum etika merupakan bagian dari pembahasan filsafat, bahkan merupakan salah satu cabang filsafat. Lebih lanjut Shidarta menyatakan tentang filsafat, pertama-tama yang harus dibedakan adalah bahwa filsafat tidak selalu diartikan sebagai ilmu. Filsafat juga dapat berarti pandangan hidup. Sebagai ilmu, filsafat merupakan proses yang terus bergulir dan tidak mengenal kata selesai. Sebaliknya filsafat sebagai pandangan hidup merupakan suatu produk (nilai-nilai atau sistem nilai) yang diyakini kebenarannya dan dapat dijadikan pedoman berperilaku oleh suatu individu atau masyarakat. Etika dapat dilihat dari pembedaan tersebut. Jadi, ada etika dalam arti ilmu (filsafat), tetapi ada pula etika sebagai sistem nilai. Etika profesi hukum sebenarnya dapat dipandang dari kedua pengertian tersebut. Jika yang dimaksud etika profesi adalah sebatas kode etik yang diberlakukan oleh masing-masing organisasi profesi hukum, hal tersebut berada dalam konteks etika sebagai sistem nilai. Namun apabila etika profesi itu dikaji secara sistematis, metodis, dan objektif untuk mencari rasionalitas di balik alasan-alasan moral dari sistem nilai yang dipilih itu, berarti etika profesi dalam hal ini merupakakan bagian atau cabang dari ilm
} 
profesi advokat, baik secara individu maupun secara kelompok. Hal tersebut berhubungan dengan sebuah nilai dalam berinteraksi menjalankan profesi keadvokatan atas kepentingan individu ataupun kelompok. Muhammad Nuh menegaskan sebagaimana berikut: Menurut etimologi (bahasa) istilah etika berasal dari kata ethos (bahasa Yunani) yang berarti karakter, watak kesusilaan, atau adat. Sebagai suatu subjek, etika berkaitan dengan konsep yang dimiliki oleh individu ataupun kelompok untuk menilai apakah tindakantindakan yang telah dilakukan dinilai benar atau salah, baik atau buruk.

Etika adalah refleksi dari self control karena segala sesuatunya dibuat dan diterapkan dari dan untuk kepentingan individu dan kelompok itu sendiri. ${ }^{4}$ Pemakaian etika dapat dirumuskan dalam arti nilai-nilai dan normanorma ${ }^{47}$ moral sebagai pegangan untuk mengatur tingkah laku advokat. Etika juga dapat dipakai dalam asas atau moral. Demikian pula etika dapat dipakai dalam arti ilmu, dan etika inilah yang sama dengan filsafat moral. Hal ini sebagaimana dimaksudkan oleh K. Bertens etika dalam rumusannya sebagai berikut: Etika dapat dipakai dalam arti nilai-nilai dan norma-norma moral yang menjai pegangan bagi seseorang atau suatu kelompok dalam mengatur tingkah lakunya. Arti ini disebut juga sebagai sistem nilai dalam hidup manusia secara individu atau kelompok, misalnya etika orang Jawa, etika Agama, dan lain-lain. Etika dapat dipakai dalam arti kumpulan asas atau nilai moral yang dimaksud ialah kode etik, misalnya kode etik advokat, kode etik dokter, dan lain-lain. Etika dapat dipakai dalam arti ilmu tentang apa yang baik atau yang buruk. Arti etika ini sama dengan filsafat moral. ${ }^{48}$ Kata ethos dalam bahasa Indonesia ternyata juga cukup banyak dipakai, misalnya dalam kombinasi etos kerja, etos profesi, etos imajinasi, etos dedikasi dan masih banyak istilah lainnya. Menurut M. Yatimin Abdullah, etika

\footnotetext{
${ }^{4}$ Muhammad Nuh, Etika Profesi, h. 17.
} 
termasuk ilmu pengetahuan tentang asas-asas tingkah laku yang berarti juga: Ilmu tentang apa yang baik, apa yang buruk, tentang hak-hak dan kewajiban.

\section{Metode Penelitian}

Pendekatan yang digunakan penulis dalam penelitian ini adalah kualitatif deskriptif, dengan menggunakan pendekatan kualitatif deskriptif merupakan metode atau cara untuk mengadakan penelitian seperti halnya penelitian non-eksperimen yang dari segi tujuannya akan diperoleh jenis atau tipe yang diambil. Pendekatan ini akan menghasilkan data deskriptif yaitu berusaha mengerti dan memahami suatu.

\section{Pembahasan}

Alquran merupakan sumber utama dan sumber pokok hukum Islam. Bagi umat Islam tidak diperbolehkan mengambil dasar hukum dan jawaban atas problematika umat Islam dari di luar Alquran selama hukum dan jawaban tersebut masih dapat ditemukan dalam nash-nash Alquran. Hal ini juga berlaku dalam merumuskan konsep etika advokat berdasarkan nilai-nilai yang terkandung dalam Alquran. Untuk mendapatkan konsep etika advokat dalam Alquran, terlebih dahulu penulis analisis dengan mengklasifikasikan ayat-ayat penegakan hukum yang berkorelasi dengan etika advokat, sehingga relevan dijadikan sebagai landasan etika advokat dalam Alquran.

Ayat-Ayat Penegakan Hukum yang Dijadikan sebagai Landasan Utama Etika Advokat. Dari sekian banyak ayat-ayat Al-quran, Moh. Amin Suma, mengemukakan bahwa ada beberapa ciri khas (karakteristik) ayat-ayat hukum yang menyebabkan kelompok ayat ini berbeda dari kelompok ayatayat lainnya. Ciri khusus ayat hukum yang dimaksud ialah: Hanya menurut norma dasar yang bersifat global; Jumlahnya relatif sedikit; Mementingkan hubungan hukum dengan akhlak termasuk wa'ad (janji baik) dan wa'id 
(ancaman buruk); Menggunakan bahasa hukum yang luas dan luwes, tetapi sekaligus juga lugas dan akurat. ${ }^{5}$

Berdasarkan ciri-ciri ayat hukum di atas dalam penelitian ini melalui pendekatan historis (historical approach), dan pendekatan konseptual (conceptual approach), penulis menemukan beberapa ayat Alquran yang relevan dengan konteks penegakan hukum, khususnya dapat dijadikan landasan etika advokat. Lebih jauh penulis bahas sebagai berikut :

\section{Q.S. an-Nisa> [4]: 58}

Terjemahan : Sesungguhnya Allah menyuruh kamu menyampaikan amanat kepada yang berhak menerimanya, dan (menyuruh kamu) apabila menetapkan hukum di antara manusia supaya kamu menetapkan dengan adil. Sesungguhnya Allah memberi pengajaran yang sebaik-baiknya kepadamu. Sesungguhnya Allah adalah Maha mendengar lagi Maha melihat.

Menurut M. Quraish Shihab dalam tafsir al-Mishbah, bahwa Q.S. anNisa [4]: 58 di atas menggunakan bentuk jamak dari kata amanat. $^{6}$ Hal ini bukan sekadar sesuatu yang bersifat material, tetapi juga non material dan bermacam-macam. Semuanya diperintahkan Allah agar ditunaikan. Ada

\footnotetext{
${ }^{5}$ Moh. Amin Suma, Pengantar Tafsir Ahkam, ( Jakarta : PT. RajaGrafindo Persada, 2002), hal.207.

${ }^{6}$ M. Quraish Shihab, Tafsir Al-Mishbah: Pesan, Kesan dan Keserasian Al-Qur'an (Volume 2: Surah Ali Imran Surah An-Nisa>), Jakarta: Lentera Hati, 2002, h. 457-458, mengemukakan bahwa Q.S. An-Nisa> ayat 58 mengungkapkan keburukan orang Yahudi, seperti tidak menunaikan amanah yang Allah percayakan kepada mereka, yakni amanah mengamalkan kita suci dan menyembunyikan isinya, kini Alquran kembali menuntun umat Islam agar tidak mengikuti jejak mereka. Tuntunan Alqur'an dalam konteks ini sangat ditekankan, karena langsung menyebut nama Allah SWT sebagai yang menuntun dan memerintahkan, sebagaimana terbaca dalam firman-Nya di atas : Sesungguhnya Allah Yang Maha Agung, Yang wajib wujud-Nya serta menyandang segala sifat terpuji lagi suci dari segala sifat tercela, menyuruh kaти menunaikan amanat-amanat secara sempurna dan tepat waktu kepada pemiliknya, yaknni yang berhak menerimanya, baik amanat Allah kepada kamu, maupun amanat manusia, baik yang berselisih dengan manusia lain maupun tanpa perselisihan, maka kamu harus menetapkan putusan dengan adil ${ }^{81}$ sesuai dengan apa yang diajarkan Allah Swt., tidak memihak kecuali kepada kebenaran dan tidak pula menjatuhkan sanksi kecuali kepada yang melanggar, tidak menganiaya walau lawanmu dan tidak pula memihak temanmu. Sesungguhnya Allah dengan memerintahkan menunaikan amanah dan menetapkan hukum dengan adil, telah memberi pengajaran yang sebaik-baiknya kepada kaтu. Karena itu berupayalah sekuat tenaga untuk melaksanakannya, dan ketahuilah bahwa Dia yang memerintahkan kedua hal ini mengawasi kamu, dan sesungguhnya Allah sejak dulu hingga kini adalah Maha Mendengar apa yang kamu bicarakan, baik dengan orang lainmaupun dengan hati kecilmu sendiri, lagi Maha Melihat sikap dan tingkah laku kamu.
} 
amanat manusia dengan Allah, antara manusia dengan manusia dengan dirinya sendiri. Masing-masing memiliki rincian, dan setiap rincian harus dipenuhi, walaupun seandainya amanat yang banyak itu hanya milik seorang. Ketika memerintahkan untuk menetapkan hukum dengan adil, ayat ini memulainya dengan menyatakan; apabila kamu menetapkan hukum di antara manusia. Tetapi sebelumnya, ketika memerintahkan menunaikan amanat, redaksi semacam ini tidak ditemukan. Ini mengisyaratkan bahwa setiap manusia telah menerima amanah secara potensial sebelum kelahirannya dan secara aktual sejak ia akil baligh. Terkait dengan itu Allah SWT berfirman: "Sesungguhnya Kami telah menawarkan amanat kepada langit, bumi dan gunung-gunung maka semuanya enggan untuk memikulnya dan mereka khawatir akan mengkhianatinya, dan dipikullah amanat itu oleh manusia. Sesungguhnya manusia itu amat zalim dan amat bodoh.” (QS. al- Ahzab [33]: 72).

M. Quraish Shihab juga menegaskan:

...menetapkan hukum bukanlah wewenang setiap orang. Ada syaratsyarat yang harus dipenuhi untuk tampil melaksanakannya, antara lain pengetahuan tentang hukum dan tata cara menetapkannya serta kasus yang dihadapi. Bagi yang memenuhi syarat-syaratnya dan bermaksud tampil menetapkan hukum, kepadanyalah ditujukan perintah di atas, yaitu kamu harus menetapkan dengan adil

Menurut Abu Ja'far Muhammad bin Jarir Ath-Thabari dalam tafsir ath-Thabari mengenai Q.S. an-Nisa [4]: 58:

Sesungguhnya Allah telah memerintahkan seorang yang diberi kuasa (pemimpin) untuk melaksanakan apa yang telah dipercayakan kepadanya berupa tanggung jawab untuk dijalankan dengan baik sesuai perintah Allah. ${ }^{7}$

\footnotetext{
${ }^{7}$ Abu Ja'far Muhammad bin Jarir Ath-Thabari, Tafsir Ath-Thabari (Jilid ke 7), Diterjemahkan oleh Akhmad Affandi dari buku asli yang berjudul "Jami 'Al Bayan an Ta'wil Ayi Al-Qur'an", (Jakarta: Pustaka Azzam, 2008), hal. 247-248.
} 
Al-Qurthubi berpendapat bahwa Q.S. an-Nisa[4]: 58 bersifat umum untuk setiap orang yaitu ditujukan untuk wali agar berlaku amanah dalam pembagian harta dan melawan kezhaliman serta berlaku dalam perkara hukum. ${ }^{8}$

Menurut pendekatan historis A. Mudjab Mahali mengemukakan bahwa, asbabun nuzul Q.S. an-Nisa> [4]: 58: Setelah kota Mekah jatuh ke tangan muslimin dengan peristiwa fathul mekah Rasulullah memanggil Utsman bin Thalhah untuk meminta kunci Ka'bah. Sewaktu Utsman bin Thalhah menghadap Rasulullah untuk menyerahkan kunci Ka'bah, Abbas berdiri seraya berkata: "Wahai Rasulullah, demi Allah. Serahkan kunci Ka'bah itu kepadaku, biar aku rangkap dengan jabatan yang selama ini, sebagai pemegang pengairan (siqayah)." Mendengar kata-kata itu Ustman bin Tahlhah menarik kembali tangannya, tidak menyerahkan kunci tersebut kepada Rasulullah. Rasulullah kemudian bersabda: "Wahai Utsman bin Thalhah, berikanlah kunci itu kepadaku!". Utsman berkata: "Ini dia, amanat dari Allah:. Selanjutnya Rasulullah berdiri membuka pintu Ka'bah, yang kemudian terus keluar melakukan tawaf di Baitullah. Sehubungan dengan itu turunlah malaikat Jibril dengan membawa perintah dari Allah agar kunci tersebut dikembalikan kepada Utsman bin Thalhah. Rasuullah pun segera melaksanakan perintah Allah itu setelah malaikat Jibril membacakan ayat 58 ini, sebagai penguat perintah tersebut. (HR. Ibnu Marduwaih dari Kalabi dari Abi Shalih dari Ibnu Abbas).

Adapun menurut Ahmad Mustofa al-Maraghi dalam tafsir al-Maraghi, amanah dibagi menjadi tiga bagian, yaitu: Amanah seorang hamba kepada Allah, yaitu segala sesuatu yang diberikan Allah kepada advokat yang haruslah dijaga dan dipelihara dengan melaksanakan perintah-Nya dan menjauhi larangannya, mengamalkan segala yang disyari'atkan dalam bidang yang

${ }^{8}$ Al-Qurthubi, Tafsir Al-Qurthubi (Jilid 5), Diterjemahkan oleh Ahmad Rijali Kadir dari buku asli berjudul “al-Jami’ li Ahkaam Alquran,( Jakarta: Pustaka Azzam, 2008), hal. 607. 
bermanfaat dalam penegakan hukum. Amanah seorang hamba pada manusia lainnya, yaitu orang yang diserahi tugas sebagai advokat, maka harus konsisten dalam mengemban amanah yang harus diberikan kepada pemiliknya tanpa mengurangi, menjaga rahasia dan yang menjadi hak orang yang berhak. Berkenaan dengan profesi advokat dalam hal ini amanat dalam membela klien yang mencari keadilan, baik di dalam persidangan maupun di luar persidangan. Amanah terhadap diri sendiri, yaitu tidak melakukan perbuatan yang merugikan diri sendiri, kecuali melakukan perbuatan yang baik dan bermanfaat bagi kemaslahatan hidup. Untuk itu dibutuhkan pengetahuan yang profesional bagi seorang advokat dalam menjalankan profesinya agar tidak salah dalam membela klien. ${ }^{9}$ Menurut Sayyid Quthb tentang Q.S. An-Nisa [4]: 58 terdapat keserasian tugas manusia untuk menyampaikan amanah dengan adil: Keserasian antara tugas-tugas yang diperintahkan, yaitu menunaikan amanat dan memutuskan perkara yang terjadi dalam kehidupan manusia dengan adil, dan antara sifat Allah "Yang Maha Mendengar lagi Maha Melihat" ada korelasi yang sangat jelas dan sekaligus lembut. Allah Maha Mendengar dan Maha Melihat masalah-masalah keadilan dan masalah-masalah amanat. Sementara itu keadilan juga membutuhkan pendengaran yang teliti, perhitungan yang baik, pertimbangan mengenai hal-hal yang samar dan jelas serta menyelami apa yang ada di balik hal-hal yang samar dan jelas tersebut. ${ }^{10}$

\section{Q.S. an-Nisa> [4]: 105}

Terjemahan: Sesungguhnya kami telah menurunkan kitab kepadamu dengan membawa kebenaran, supaya kamu mengadili antara manusia dengan apa yang telah Allah wahyukan kepadamu, dan janganlah kamu menjadi penantang (orang yang tidak bersalah), karena (membela) orang-orang yang khianat.

\footnotetext{
${ }^{9}$ Ahmad Mustofa al- Maraghi, Terjemah Tafsir Al-Maraghi (Juz 5), Diterjemahkan oleh Bahrun Abubakar dan Hery Noer Aly dari buku asli yang berjudul ' Tafsir Al- Maraghi',( Semarang: PT. Karya Toha Putra Semarang, 1986), hal.113-115.

${ }^{10}$ Sayyid Quthb, Tafsir Fi-Zhilalil Qur'an: Di Bawah Naungan Al-Qur'an (Jilid 5: Juz 5 dan 6), Diterjemahkan oleh Aunur Rafiq Shaleh Tamhid dan Khoirul Halim dari buku asli yang berjudul "FiZhilalil Qur'an", (Jakarta: Robbani Press, 2002), hal. 160
} 
M. Quraish Shihab berpendapat tentang Q.S. an-Nisa [4]: 105, pada kata al-haq, dalam ayat ini memiliki makna sesuatu yang mantap tidak berubah yang berkisar pada kemantapan sesuatu dan kebenarnnya. M. Quraish Shihab menerangkan bahwa:

Kata $a l-h a q$, terdiri dari huruf-huruf ha dan qaf, maknanya berkisar pada kemantapan sesuatu dan kebenarannya. Sesuatu mantap tidak berubah, dinamai haq, demikian juga yang mesti dilaksanakan atau yang wajib. Lebih lanjut tentang haq, M. Quraish Shihab menjelaskan bahwa: Nilai-nilai agama adalah haq karena nilai-nilai itu selalu mantap, tidak dapat diubah-ubah. Sesuatu yang tidak berubah, sifatnya pasti, dan sesuatu yang pasti, menjadi benar, dari sisi bahwa ia tidak mengalami perubahan. Nilai-nilai yang diajarkan Alquran adalah haq. Dia diturunkan dengan haq dalam arti tidak disentuh oleh kebatilan tidak juga dapat dibatalkan atau dilenyapkan oleh kenyataan. M. Quraish Shihab menerangkan sejarah turunnya ayat ini adalah: Mayoritas ulama tafsir mengemukakan suatu peristiwa yang mereka nilai berhubungan dengan turunnya ayat ini. Kesimpulannya adalah bahwa ada seorang bernama Thu'mah ibn Ubairiq yang mencuri perisai tetangganya yang bernama Qatadah ibn Nu'man. Perisai itu berada dalam satu kantong yang berisi tepung. Thu'mah menyembunyikan perisai itu di rumah seorang Yahudi bernama Zaid ibn as-Samin. Rupanya kantong tempat perisai itu bocor. Ketika pemilik perisai mengetahui kehilangan perisainya, ia bertanya kepada Thu'mah tetapi ia bersumpah tak tahu menahu. Melalui tetesan tepung mereka menemukan perisai itu di rumah Zaid ibn as- Samin, Yahudi itu. Tentu saja ia menolak tuduhan bahkan mengatakan Thu'mahlah yang menitipkan perisai itu kepadanya. Beberapa orang Yahudi ikut menjadi saksi kebenaran Zaid. Namun keluarga Thu'mah mengadu kepada Rasul serta membela Thu'mah. Rasul hampir terpengaruholeh dalih-dalih yang dikemukakan mereka sehingga terlintas dalam pikiran beliau, bahkan hampir saja beliau menjatuhkan sanksi 
kepada si Yahudi, untung ayat ini turun meluruskan apa yang hampir keliru itu. Ahmad Mustofa al-Maraghi berpendapat tentang Q.S. an- Nisa[4]: 105, bahwa: Janganlah kamu bersikap meremehkan di dalam meneliti haq karena tertipu oleh pembicaraan orang-orang yang berkhianat dan kepandaiannya di dalam berdebat, agar kamu tidak menjadi penantang kebenaran demi membela mereka yang berkhianat. Menurut Abu Ja'far Muhammad bin Jarir Ath-Thabari tentang Q.S. an-Nisa> [4]: 105, bahwa: Tidak membela orang yang berkhianat, makdsudnya tidak membela kesalahan orang yang salah. Al-Qurthubi juga menegaskan bahwa orang yang berdebat membela kesalahan orang yang salah, sebagaimana berikut: Seseorang yang mendebat orang lain kecuali ia tahu bahwa dirinya berada dalam kebenaran seperti berdebat dalam rangka mempertahanan harta anak yatim dan orang lain, maka harta orang kafir pun wajib dibela dan dijaga sebagaimana harta orang muslim, kecuali pada hal-hal yang dibolehkan Allah SWT. Sayyid Quthb menerangkan bahwa dalam Q.S. An-Nisa> [4]: 105, terdapat konsep penegakan hukum. Secara tegas menurutnya: Permasalahannya di sini tidak sekadar membebaskan orang yang tidak bersalah yang menjadi korban atau tertuduh sebagai hasil rekayasa dari kelompok tertentu, meskipun membebaskan orang yang tidak bersalah tersebut merupakan sesuatu perkara yang besar dan tinggi nilainya menurut Allah. Tetapi permasalahannya jauh lebih besar dari itu. Permasalahannya disini adalah membangun timbangan yang tidak berat sebelah karena faktor hawa nafsu atau fanatisme dan tidak terpengaruh oleh perasaan kasihan atau benci dikarenakan berbagai faktor keadaan. Mahmud Syaltut menyimpulkan, bahwa Q.S. An-Nisa [4]:105 mengandung konsep tugas penegak hukum yaitu advokat dalam menegakkan keadilan. Dalam menegakkan keadilan, harus memeriksa secara seksama tentang proses pencarian kebenaran dan keadilan yang tidak menyalahi fakta. 


\section{Q.S. an-Nisa [4]: 135}

Artinya: Wahai orang-orang yang beriman, jadilah kamu orang yang benar-benar penegak keadilan, menjadi saksi Karena Allah biarpun terhadap dirimu sendiri atau ibu bapak dan kaum kerabatmu. jika ia kaya ataupun miskin, maka Allah lebih tahu kemaslahatannya. Maka janganlah kamu mengikuti hawa nafsu karena ingin menyimpang dari kebenaran. dan jika kamu memutar balikkan (kata-kata) atau enggan menjadi saksi, maka sesungguhnya Allah adalah Maha mengetahui segala apa yang kamu kerjakan. Berdasarkan pendekatan historis menurut Jalaluddin As-Suyuthi, sebab turunnya Q.S. an-Nisa> [4]: 135, bahwa:

Ibnu Hatim meriwayatkan bahwa as-Suddi berkata, "ayat ini turun pada Rasulullah SAW, ketika seorang kaya dan fakir berselisih dan mengadukannya kepada beliau. Dan rasulullah SAW memihak orang fakir karena menurut beliau orang fakir tidak menzalimi orang kaya. Sedangkan Allah tetap ingin agar beliau berlaku adil kepada orang kaya dan fakir tersebut. ${ }^{11}$ Secara tegas M. Quraish Shihab menginterpretasikan ayat tersebut sebagai berikut:

Wahai orang-orang yang beriman, jadilah penegak keadilan yang sempurna lagi sebenar-benarnya, menjadi saksi-saksi karena Allah, yakni selalu merasakan kehadiran Ilahi, memperhitungkan segala langkah kamu dan menjadikannya demi karena Allah, biarpun keadilan yang kamu tegakkan itu terhadap dirimu atau terhadap ibu bapak dan kaum kerabat kamu, misalnya terhadap anak, atau saudara dan paman kamu sendiri. Jika ia, yakni pribadi yang disaksikan itu kaya, sehingga boleh jadi kamu harapkan bantuannya atau dia disegani dan ditakuti, ataupun miskin yang biasanya dikasihi, sehingga menjadikan kamu bertindak tidak adil guna memberinya manfaat atau menolak mudharat yang dapat jatuh atas mereka, maka sekali-kali jangan jadikan kondisi itu alasan untuk tidak menegakkan keadilan demi karena Allah. Maka janganlah kamu mengikuti hawa nafsu karena itu menyimpang dari kebenaran. Dan jika kamu memutar-balikkan kata-kata dengan mengurangi kesaksian, atau menyampaikannya secara palsu, atau berpaling, enggan menjadi saksi, maka sesungguhnya Allah senantiasa Maha Mengetahui segala apa yang kamu kerjakan yang sekecil-kecilnya sekalipun. ${ }^{208}$ Ahmad Mustofa al-Maraghi

${ }^{11}$ Jalaluddin As-Suyuthi, Sebab Turunnya Ayat Al-Qur'an, Diterjemahkan oleh Tim Abdul Hayyie dari buku asli yang berjudul "Lubaabun Nuquul fii Asbaabin Nuzuul", (Jakarta: Gema Insani, 2008), hal. 206 
berpendapat tentang Q.S. an- Nisa> [4]: 135, bahwa: Hendaklah perhatian terhadap menegakkan keadilan dengan sempurna kalian jadikan sebagai sifat yang tetap dan melekat dalam jiwa kalian. Menegakkan keadilan bisa dilakukan dalam memerintah umat manusia bagi orang yang diangkat oleh sultan sebagai wali atau dijadikan sebagai hakim oleh orang- orang untuk memutuskan perkara-perkara mereka. Bisa pula dilakukan di dalam pekerjaan lain, seperti menegakkan kewajiban persamaan para istri dan anak-anak. Sekiranya kaum muslimin mengikuti petunjuk Alquran, tentulah mereka menjadi umat yang paling adil dan bisa menegakkan keadilan.

Q.S. an-Nisa[4]: 135 menyerukan agar keadilan dilaksanakan secara tegas terhadap setiap orang, baik keluarga sendiri ataupun orang lain, baik orang kaya ataupun miskin. Atribut lahiriah tidak boleh dijadikan alasan dalam suatu penetapan hukum. Kandungan Q.S. an-Nisa[4]: 135 yaitu amanah menegakkan keadilan secara total. Secara tegas Sayyid Quthb menyatakan bahwa: Keadilan total dalam semua kondisi dan dalam semua bidang. Keadilan mencegah terjadinya tindakan semena-mena dan kezhaliman di muka bumi. Keadilan di antara manusia yang menjamin sampainya suatu hak kepada pemilik hak, apakah ia dari kalangan muslim atau dari kalangan non muslim. ${ }^{12}$ Berdasarkan konteks di atas dengan tegas Abu Ja'far Muhammad bin Jarir Ath-Thabari berpendapat tentang Q.S. an-Nisa 4]: 135, bahwa kesamaan di depan hukum, berlaku adil kepada semua, baik miskin, kaya, ibu, ayah, atau kelurga. Mengenai Q.S. an-Nisa> [4]: 135, ini yang dijadikan sebagai dasar hukum, Al-Qurthubi berpendapat, bahwa para ulama tidak berbeda pendapat tentang keabsahan hukum-hukum yang ada pada ayat ini. Kandungan Q.S. an-Nisa> [4]: 135, secara umum Allah SWT memerintahkan agar berlaku adil sesama manusia, karena dengan tegaknya keadilan akan tercapai kemaslahatan umat. Di samping itu dalam menegakkan keadilan harus mengutamakan kebenaran, meskipun terhadap diri sendiri, kedua orang tua, dan kaum kerabat, tanpa membeda-bedakan status sosial, kaya

${ }^{12}$ Sayyid Quthb, Tafsir Fi-Zhilalil Qur'an, hal. 357 
ataupun miskin.Menurut penulis kandungan ayat ini memiliki nilai yang dapat dijadikan sebagai etika advokat, seperti profesional, prinsip kesamaan hukum, dan prinsip objektif pada kebenaran dengan tidak mengikuti hawa nafsu atau kepentingan yang memihak pada diri sendiri, kedua orang tua, kaum kerabat atau keluarga untuk mencapai keadilan dan kemaslahatan. Hal ini termasuk cerminan dari nilai dasar etika advokat dalam Alquran, yaitu amanah dan adil. Berdasarkan analisis penulis di atas, terhadap Q.S. an-Nisa [4]: 58, 105, dan 135, relevan dijadikan sebagai ayat-ayat yang menjadi landasan etika advokat dalam Alquran. Sebab, ayat-ayat tersebut memenuhi klasifikasi tentang ayat penegakan hukum melalui pendekatan historis (historical approach), yang melatarbelakangi sebab turunnya ayat tentang pengakan hukum tersebut, dan kandungan ayat tersebut berdasarkan pendekatan konseptual (conceptual approach), relevan dengan konsep penegakan hukum, sehingga tepat dijadikan landasan etika advokat. Konsep tersebut mengandung nilai dasar yang relevan dijadikan sebagai landasan etika advokat berdasarkan nilai qur'a>ni, yaitu $a m a>n a>h$ mengandung nilai kejujuran, objektivitas, profesionalitas. Sedangkan adil mengandung nilai totalitas dalam menegakkan hukum sebagai kemaslahatan di dunia dan di akhirat.

Sebagaimana analisis yang telah dibahas penulis di atas mengenai ayat-ayat yang menjadi landasan utama etika advokat dalam Alquran, yaitu Q.S. an-Nisa[4]: 58, 105, dan 135. Berdasarkan kandungan ayat-ayat tersebut terdapat nilai dasar berupa konsep etika advokat yaitu, amanah dan adil. Konsep tersebut mengandung nilai dasar yang relevan dijadikan sebagai landasan etika advokat berdasarkan nilai qur'a>ni, yaitu amanah mengandung nilai kejujuran, objektivitas, profesionalitas. sedangkan adil mengandung nilai totalitas dalam menegakkan hukum sebagai kemaslahatan di dunia dan di akhirat. Konsep tersebut dapat dirumuskan menjadi etika advokat dalam 
beberapa standar perilaku. Penulis merumuskan standar perilaku tersebut, sebagai berikut: Advokat dituntut memiliki sikap, perilaku, dan kepribadian yang terpuji dalam menjalankan profesi dengan menjunjung tinggi keadilan dan amanah, yang terbagi menjadi: pertama, adil terhadap Allah SWT dengan beriman dan bertakwa; kedua, adil kepada orang lain, baik klien, rekan sesama advokat, penegak hukum lainnya, seperti polisi, jaksa, dan hakim; ketiga, adil kepada masyarakat, sesuai dengan $a m a>n a>h$ atau kebenaran yang sebenarnya. $A m a>n a>h$ dan adil merupakan dasar moralitas profesi advokat yang menjamin moral advokat agar tidak melakukan kesalahan dalam memberikan bantuan hukum demi menjaga kepribadian, profesionalitas, martabat dan wibawa, dan kepercayaan masyarakat pencari keadilan terhadap advokat sebagai profesi terhormar.

Advokat melaksanakan tugas dengan amanah dan adil, maksudnya memposisikan diri dengan amanah sesuai profesionalitas yang dijalankan dengan amanah. Menjaga amanah yang tertuang dalam hukum yang berlaku, baik hukum agama (hukum Islam), dan hukum positif yang berlaku pada suatu masyarakat sesuai dengan legalitas hukum. Menjalankan tugas sesuai batas kewajaran hukum yang berlaku sesuai dengan dasar etika yang mengacu pada amanah dan adil dalam Alquran.

Advokat sebagai penegak hukum yang memberikan bantuan hukum, baik berupa penasehatan, dan pembelaan di dalam persidangan dan di luar persidangan mengutamakan sikap $a m a>n a>h$ dan adil. Pelayan terhadap klien harus sesuai dengan dasar etika tersebut, baik dalam menerima dan mengurus perkara, menjaga rahasia klien, menentukan honorarium, dan memposisikan klien pada keadaan yang sebenarnya dengan batas kewajaran dalam hukum positif yang harus dilandasi dasar etika advokat dalam Alquran.

Kedudukan advokat sebagai penegak hukum yang sejajar dengan polisi, jaksa, dan hakim sehingga dalam menjalankan profesinya advokat saling 
berintegrasi dalam menegakkan hukum, dan juga berlaku antar sesama profesi advokat dengan tujuan menegakkan hukum yang berdasarkan dasar etika advokat dalam nilai Alquran, yaitu amanah dan adil. Dengan demikian, advokat memposisikan diri sesuai sikap amanah dan adil dengan sesama penegakkan hukum.

Pengawasan yang dilakukan terhadap advokat dalam menjalankan profesi dilakukan oleh Dewan Kehormartan Pusat maupun Cabang yang berwenang mengawasi dan melakukan penindakan pemberian sanksi dengan dasar nilai qur'ani yaitu amanah dan adil dalam mengawasi dan memberikan sanksi kepad advokat yang melakukan pelanggaran kode etik advokat. Pengawasan yang dilakukan harus berimbang dengan nilai dasar etika advokat dalam Alquran, yakni amanah dan adil.

Advokat diwajibkan patuh dan taat terhadap hukum yang berlaku. Sebab, advokat merupakan profesi penegak hukum, dan sudah sepantasnya wajib mentaati hukum yang berlaku agar tidak merusak wibawa dan martabatnya. Advokat yang Bergama Islam patuh dan tunduk pada hukum Islam dan wajib mengamalkan Alquran sebagai pedoman dalam menjalankan profesi. Konsep etika advokat dalam Alquran di atas, menurut penulis wajib diterapkan sebagai etika advokat (advokat yang beragam Islam) dalam menjalankan profesi. Konsep etika advokat tersebut dalam aplikasinya dan konteksnya dengan penerapan hukum Islam juga berhubungan dengan kaidah fikih yang mendukung penegakan hukum yang sesuai dengan penerapan etika advokat dalam Alquran. Menurut penulis kaidah fikih yang berhubungan dan mendukung penegakan hukum dalam penerapan etika advokat tersebut, Sebagai berikut : 
Terjemahan: Kemaslahatan publik didahulukan daripada kemaslahatan individu. ${ }^{13}$

Terjemahan : Perbuatan yang mencakup kepentingan orang lain lebih utama daripada yang hanya terbatas untuk kepentingan sendiri. ${ }^{14}$

Berdasarkan kaidah di atas bahwa suatu perbuatan yang dapat menghasilkan kemanfaatan yang dapat mencakup kepada orang lain, yakni dirasakan kemanfaatannya oleh orang lain yang tidak melakukan perbuatan itu, maka lebih baik daripada suatu perbuatan yang manfaatnya hanya dapat dirasakan oleh orang yang melakukannya itu saja. Hal ini menunjukkan perilaku advokat yang menegakkan kebenaran berdasarkan Alquran dapat mendatangkan kemaslahatan di dunia dan di akhirat.

Kaidah-kaidah fikih di atas adalah kaidah fikih tentang penegakan hukum yang sesuai dengan penerapan etika advokat dalam Alquran yang pada pokoknya menuju kemaslahatan. Sebagaimana kaidah fikih berikut:Artinya: Menolak mafsadah didahulukan kepada meraih maslahat. $^{241}$

\section{Bentuk Kolaborasi Etika Advokat dalam Alquran dengan} Undang- Undang Nomor 18 Tahun 2003 tentang Advokat, dan Kode Etik Advokat Indonesia Tahun 2002. Berkaitan dengan sistem hukum, John Pieris mengemukakan pendapat John Rawls dalam A Theory of Justice, yaitu: Semua sistem hukum akan gagal, bila tidak disemangati suatu sikap moral pribadi yang sejati (justice as fairness). Dikatakannya, bahwa beberapa prinsip konkret harus membimbing para penguasa untuk mewujudkan suatu keadilan yang memadai. Pandangan John Rawls penting untuk dipahami, dan disikapi bahwa sikap moral pribadi harus diwujudkan dalam menentukan politik

${ }^{13}$ Djazuli, Kaidah-kaidah Fikih: Kaidah-kaidah Hukum Islam dalam Menyelesaikan Masalah-masalah yang Praktis, (Jakarta: Kencana, 2007), hal. 11.

${ }^{14}$ Musbikin, Imam, Qawa'id al-fiqhiyah,( Jakarta: PT. RajaGrafindo Persada, 2001), hal.150-151. 
hukum dan pembentukan hukum, terutama undang-undang. Pandangan ini juga perlu diterapkan dalam proses penegakan hukum dan keadilan, serta pembentukan karakter, etik dan moral aparat penegak hukum terutama advokat dan masyarakat. Jika pilihan moral ini diterapkan, maka wibawa hukum akan relevan dengan kondisi penegakan hukum yang bertujuan mewujudkan keadilan, kepastian, dan kemanfaatan, khususnya etika advokat dalam menjalankan profesi hukum. ${ }^{15}$ John Pieris juga mengemukakan bahwa Lawrence W. Friedman, menawarkan tiga elemen penting dalam efektifitas proses penegakan hukum yang berkeadilan dalam sistem hukum, yaitu: Struktur (structure), substansi (substance), dan budaya hukum (legal culture). Menurutnya, struktur merupakan kerangka dari sistem hukum yang terwujud dalam lembaga-lembaga dan aparat penegak hukum di dalam lembaga tersebut. Substansi merupakan peraturan- peraturan hukum serta norma dan perilaku dari aparat penegak hukum di dalam sistem. Sedangkan budaya hukum merupakan tingkat kualitas penataan terhadap hukum. ${ }^{16}$

Immanuel Kant menyatakan bahwa hukum sebagai suatu sistem dapat diklasifikasikan menjadi dua jenis, yaitu: Hukum kodrat adalah norma yang ditetapkan oleh Tuhan yang mengandung prinsip prinsip a priori (nilai). Hukum positif adalah norma aturan buatan manusia (pembentuk undang-undang) yang mengandung prinsip-prinsip yang dikehendaki oleh pembentuk undangundang. Menurut Abdulkadir Muhammad, apabila konsep hukum positif Immanuel Kant ini dikembangkan, maka yang dimaksud dengan manusia dapat berupa penguasa (pembentuk undang-undang), kelompok masyarakat umum dan kelompok profesi. Dengan demikian, hukum positif adalah: Norma

15 John Pieris, Etika dan Penegakan Kode Etik Profesi Hukum (Advokat), (Jakarta: BadanPembinaan Hukum Nasional Departemen Hukum dan Hak Asasi Manusia RI, 2008), hal. 74-75.

${ }^{16}$ Ibid., hal. 75-76. 
buatan penguasa disebut undang-undang; Norma buatan kelompok masyarakat umum disebut kebiasaan; Norma buatan kelompok profesi disebut kode etik. ${ }^{245}$

Secara konkret hukum positif undang-undang mempunyai legalitas dan keberlakuannya menjadi acuan hukum kebiasaan dan kode etik, karena dibuat oleh penguasa (pembentuk undang-undang). Hal ini perlu disesuaikan dengan hukum tertinggi bagi umat Islam, khsususnya advokat yang beragama Islam, selain menjalankan profesi berdasarkan hukum positif harus menjunjung tinggi Alquran sebagai pedoman hidup yang utama. Sehingga diperlukan penggalian etika advokat dalam Alquran dengan Undang-Undang Nomor 18 Tahun 2003 tentang Advokat, dan Kode Etik Advokat Indonesia Tahun 2002. Hal ini merupakan bentuk kolaborasi hukum positif dengan hukum kodrat berupa norma yang ditetapkan Allah SWT dalam Alquran, dalam konteks pembentukan dan pembangunan hukum tentang etika advokat dalam Alquran dengan hukum positif, dalam bentuk kolaborasi nilai qur'a $>$ ni dengan Undang-Undang Nomor 18 Tahun 2003 tentang Advokat, dan Kode Etik Advokat Indonesia Tahun 2002. Penulis paparkan dengan beberapa bahasan yang sesuai dengan etika advokat dalam Alquran menurut Q.S. anNisa> [4]: 58, 105, dan 135, dengan hukum positif, yaitu bentuk kolaborasi nilai qur'a>ni dengan Undang- Undang Nomor 18 Tahun 2003 tentang Advokat, dan Kode Etik Advokat Indonesia Tahun 2002 sebagai berikut: Kolaborasi Nilai Qur'ani dengan Undang-Undang Nomor 18 Tahun 2003 tentang Advokat. Pada Pasal 1 ayat (1) Undang-Undang Nomor 18 Tahun 2003 tentang Advokat, menjelaskan bahwa: advokat adalah orang yang berprofesi memberi jasa hukum, baik di dalam maupun di luar pengadilan yang memenuhi persyaratan berdasarkan ketentuan Undang-Undang ini. Pasal ini menjelaskan posisi advokat dalam amanat konstitusi.

Pada Pasal tersebut terdapat nilai qur'ani yaitu amanah, yang sesuai dengan kandungan etika advokat dalam Q.S. an-Nisa [4]: 58, 105, dan 135. 
Amanat Undang-undang termasuk amanah seorang manusia pada manusia lain, yaitu secara konkret menjadi suatu hukum dengan melalui positivisasi menjadi Undang-undang. Amanat Undang-undang dalam Pasal 1 ayat (1) tersebut adalah amanah kepada advokat agar benar-benar sebagai penegak hukum yang berdasarkan nilai qur'ani yaitu amanah dan adil, mencakup perilaku baik, jujur, adil, bertanggung jawab, profesional dengan memiliki keahlian profesi hukum, dan mempunyai integritas yang tinggi dalam menjalankan profesi sebagai penegak hukum. Nilai-nilai qur'a>ni dalam Q.S. an-Nisa [4]: 58, 105, dan 135, berkolaborasi dengan profesi advokat dalam Pasal lainnya, di antaranya: Pengangkatan advokat Pasal 2 ayat (1) dan (2), Pasal 3 ayat (1) dan (2); Sumpah Pasal 4; Status Pasal 5; Penindakan Pasal 6, 7, dan 8; Pemberhentian Pasal 9, 10, 11; Pengawasan Pasal 12 dan 13; Hak dan Kewajiban Advokat Pasal 14, 15, 16, 17, 18, 19, 20; Honorarium Pasal 21; Bantuan Hukum Cuma-cuma Pasal 22; Advokat Asing Pasal 23, dan 24; Atribut Pasal 25; Kode Etik dan Dewan Kehormatan Advokat Pasal 26, dan 27; Organisasi Advokat Pasal 28, 29, 30.

Berdasarkan bahasan di atas, menurut penulis kolaborasi nilai qur'ani dengan Undang-Undang Nomor 18 Tahun 2003 tentang Advokat, merupakan refleksi kandungan Q.S. an-Nisa [4]: 58, 105, dan 135, mengacu pada konsep etika advokat dalam Alquran, yaitu amanah dan adil. Kolaborasi Nilai qur'ani dengan Kode Etik Advokat Indonesia Tahun 2002

Pada paragaraf 2 pembukaan Kode Etik Advokat Indonesia Tahun 2002, disebutkan bahwa: Advokat sebagai profesi terhormat (officium nobile) yang dalam menjalankan profesinya berada di bawah perlindungan hukum, 
Undang-undang dan Kode Etik, memiliki kebebasan yang didasarkan kepada kehormatan dan kepribadian advokat yang berpegang teguh kepada kemandirian, kejujuran, kerahasiaan dan keterbukaan. ${ }^{17}$ Dapat dijelaskan, bahwa hakikat profesi advokat mendapat perlindungan hukum dalam Undangundang dan kode etik, hal ini juga disebutkan pada Pasal 1 (a) Kode Etik Advokat Indonesia, yang menunjukkan adanya amanah dari Undang-undang dan kode etik yang berarti, ada amanah dari orang-orang atau kumpulan kelompok pembentuk hukum dalam merumuskan hukum (etika advokat), yaitu kumpulan standar perilaku bagi advokat dalam menjalankan profesinya secara lebih konkret dibentuk kode etik oleh kumpulan profesi advokat dalam organisasi advokat, sehingga di sini amanah yang dimaksud merupakan kandungan dari nilai qur'ani dalam Q.S. an-Nisa [4]: 58, 105, dan 135, mengacu pada konsep etika advokat dalam Alquran, yaitu amanah dan adil. Kandungan nilai qur'a $>$ ni tersebut, disebut pada paragraf 2 Kode Etik Advokat Indonesia, bahwa kebebasan advokat dalam menjalankan profesi dengan kepribadian yang berpegang teguh kepada kemandirian, kejujuran, kerahasiaan dan keterbukaan. Hal ini menunjukkan nilai qur'a>ni dalam Q.S. an-Nisa [4]: 58, 105, dan 135, yaitu amanah dan adil, mencakup perilaku baik, jujur, adil, bertanggung jawab, profesional dengan memiliki keahlian profesi hukum, dan mempunyai integritas yang tinggi dalam menjalankan profesi sebagai penegak hukum. Nilai qur'ani tersebut juga terdapat dalam beberapa bahasan Kode Etik Advokat Indonesia, sebagaimana berikut; Kepribadian Advokat Pasal 2, Pasal 3; Hubungan dengan Klien Pasal 4; Hubungan dengan Teman Sejawat Pasal 5; Tentang Sejawat Asing Pasal 6; Cara Bertindak Menangani Perkara Pasal 7; Ketentuan-ketentuan Lain tentang Kode Etik Pasal 8; Pelaksanaan Kode Etik Pasal 9;

${ }^{17}$ Kode Etik Advokat Indonesia, dalam Artidjo Alkostar, Peran dan Tantangan, hal. 189. 
Berdasarkan bahasan di atas, menurut penulis beberapa ketentuan yang tertuang dalam Kode Etik Advokat Indonesia Tahun 2002 merupakan refleksi kandungan Q.S. an-Nisa> [4]: 58, 105, dan 135, mengacu pada konsep etika advokat dalam Alquran, yaitu amanah dan adil. Bentuk kolaborasi nilai qur'a>ni dengan Undang-Undang Nomor 18 Tahun 2003 tentang Advokat, dan Kode Etik Advokat Indonesia di atas, merupakan perpaduan sikap amanah dan adil, mencakup perilaku baik, jujur, adil, bertanggung jawab, profesional dengan memiliki keahlian profesi hukum, dan mempunyai integritas yang tinggi dalam menjalankan profesi sebagai penegak hukum.

Berdasarkan hasil penelitian yang telah dilakukan, maka yang dapat disimpulkan sebagai berikut: Ayat-ayat yang menjadi landasan utama etika advokat sebagaimana Kode Etik Advokat Indonesia Tahun 2002 Bab II Pasal 2 tentang Kepribadian Advokat, mempunyai relevansi dengan Alquran dalam Q.S. an-Nisa [4]: 58, 105, dan 135, yang sesuai konsep penegakan hukum dalam Alquran. Ayat-ayat tersebut menunjukkan standar perilaku yang sesuai dengan etika penegak hukum, sebagaimana konteks turunnya ayat dan konsep penegakkan hukum sebagai etika advokat. Konsep etika advokat berdasarkan nilai qur'a>ni mengacu pada konsep dasar etika advokat dalam Alquran, yaitu sikap $a m a>n a>h$ dan adil, mencakup standar perilaku perilaku hukum, yaitu baik, jujur, adil, bertanggung jawab, profesional dengan memiliki keahlian profesi hukum, dan mempunyai integritas yang tinggi dalam menjalankan profesi sebagai advokat, dengan dilindungi oleh hukum positif. Amanah mengandung nilai kejujuran, objektivitas, profesionalitas. sedangkan adil mengandung kemaslahatan bagi pencari keadilan. Konsep tersebut diterapkan pada etika kepribadian advokat, etika melakukan tugas jabatan, etika pelayanan terhadap klien, etika hubungan dengan sesama penegak hukum, dan etika pengawasan advokat. Pada penerapannya konsep tersebut juga didukung oleh kaidah fikih tentang penegakan hokum. Penerapan konsep etika advokat dalam Alquran secara konkret dapat diterapkan melalui hukum positif. Nilai qur'a>ni yang terdapat pada Undang-Undang Nomor 18 Tahun 2003 tentang Advokat, dan Kode Etik Advokat Indonesia Tahun 2002 merupakan bentuk kolaborasi etika advokat berdasarkan nilai qur'āni 
dengan Undang-Undang Nomor 18 Tahun 2003 tentang Advokat, dan Kode Etik Advokat Indonesia Tahun 2002 Bab II Pasal 2 tentang Kepribadian Advokat.

\section{E. Kesimpulan}

Berdasarkan hasil penelitian yang telah dilakukan oleh penulis, maka yang dapat disimpulkan sebagai berikut: Ayat-ayat yang menjadi landasan utama etika advokat sebagaimana Kode Etik Advokat Indonesia Tahun 2002 Bab II Pasal 2 tentang Kepribadian Advokat, mempunyai relevansi dengan Alquran dalam Q.S. an-Nisa> [4]: 58, 105, dan 135, yang sesuai konsep penegakan hukum dalam Alquran. Ayat-ayat tersebut menunjukkan standar perilaku yang sesuai dengan etika penegak hukum, sebagaimana konteks turunnya ayat dan konsep penegakkan hukum sebagai etika advokat. Selain ayat-ayat tersebut ada ayat-ayat lain sebagai pendukung etika advokat, yaitu Q.S. an-Nisa> [4]: 107, 109, 111,112, dan 113, Q.S. al-Ma>idah [5]: 8, Q.S. an-Na>hl [16]: 90, Q.S. al-Isra>’ [17]: 36, dan Q.S. as $\}-S\{a>d$ [38]: 26.

\section{Literatur}

\section{Daftar Pustaka}

Abdullah, M. Yatimin, Pengantar Studi Etika, Jakarta: PT. RajaGrafindo Persada, 2006.

Abdurrahman, Beberapa Aspekta Tentang Pembangunan Hukum Nasional, Bandung: Citra Aditya Bakti, 1995.

Abdul Baqi, Muhammad Fuad, Al-lu'lu' wal Marjan (Ensiklopedi HaditsHadits Shahih yang Disepakati Oleh Bukhari dan Muslim Jilid 2), Diterjemahkan oleh M.A. Imran Anhar dan Luqman Abdul Jalal, Jakarta: Pustaka as- Sunnah, 2008.

Alkostar, Artidjo, Peran dan Tantangan Advokat dalam Era Globalisasi, Yogyakarta: FH UII Press, 2010.

Al-Albani, Muhammad Nashiruddin, Shahih Sunan Abu Daud (Buku 2), Diterjemahkan oleh Abd. Mufid Ihsan dan M. Soban Rohman, Jakarta: Pustaka Azzam, 2006. 
Al-Albani, Muhammad Nashiruddin, Shahih at-Targhib wa at-Tarhib, Diterjemahkan oleh Izzudin Karimi, Mustofa Aini, dan Kholid Samhudi, Jakarta: Pustaka Sahifa, 2008.

Al-Albani, Muhammad Nashiruddin, Shahih Sunan Nasa’i, Diterjemahkan oleh Kamaluddin Sa'diyyatul Haramain, Jakarta: Pustaka Azzam, 2007.

Al-Maraghi, Ahmad Mustofa, Terjemah Tafsir Al-Maraghi (Juz 4, 5, dan $6)$,

Diterjemahkan oleh Bahrun Abubakar dan Hery Noer Aly dari buku asli yang berjudul "Tafsir Al-Maraghi", Semarang: PT. Karya Toha Putra Semarang, 1986.

Ali, Mohammad Daud, Hukum Islam: Pengantar Ilmu Hukum dan Tata Hukum Islam di Indonesia, Jakarta: PT. RajaGrafindo Persada, 2002.

Ali, Zainuddin, Hukum Islam (Pengantar Hukum Islam di Indonesia), Jakarta: Sinar Grafika, 2008.

Al-Qurthubi, Tafsir Al-Qurthubi (Jilid 5), Diterjemahkan oleh Ahmad Rijali Kadir dari buku asli berjudul 'al-Jami' li Ahkaam Alquran, Jakarta: Pustaka Azzam, 2008.

Amin, Ahmad, Etika (Ilmu Akhlak), Jakarta: Bulan Bintang, 1975. Anwar, Rosihan, Ulum Al-Qur'an, Bandung: Pustaka Setia, 2010.

Asmaran, Pengantar Studi Akhlak, Jakarta: PT. RajaGrafindo Persada, 1994.

As-Suyuthi, Jalaluddin, Sebab Turunnya Ayat Al-Qur'an, Diterjemahkan oleh Tim Abdul Hayyie dari buku asli yang berjudul "Lubaabun Nuquul fii Asbaabin Nuzuul”, Jakarta: Gema Insani, 2008.

Ath-Thabari, Abu Ja'far Muhammad bin Jarir, Tafsir Ath-Thabari (Jilid ke 7), Diterjemahkan oleh Akhmad Affandi dari buku asli yang berjudul "Jami 'Al Bayan an Ta'wil Ayi Al-Qur'an', Jakarta: Pustaka Azzam, 2008. Azizy, A. Qodri, Eklektisisme Hukum Nasional, Yogyakarta: Gama Media, 2002.

Az-Zuhaili, Wahbah, Fiqih Islam wa Adillatuhu: Jihad, Pengadilan dan Mekanisme Mengambil Keputusan, Sistem Pemerintahan dalam Islam (Jilid 8),Diterjemahkan oleh Abdul Hayyie al-Kattani, dkk, Jakarta: GemaInsani, 2011.

Badroen, Faisal, dkk, Etika Bisnis dalam Islam, Jakarta: Kencana, 2007. 
ISSN : $1829-8257$

IAIN Palangka Raya

Badudu, J.S., dan Zain, Sutan Muhammad, Kamus Umum Bahasa Indonesia, Jakarta: Pustaka Sinar Harapan, 1994.

Baidan, Nashuruddin, Metode Penafsiran Al-Qur'an: Kajian Kritis terhadap Ayat-Ayat yang Beredaksi Mirip, Yogyakarta: Pustaka Pelajar, 2002.

Bagus Pratama, Aditya, Kamus Lengkap Bahasa Indonesia, Surabaya: Pustaka Media, 2012.

Bertens, K., Etika, Jakarta: Gramedia Pustaka Utama, 2005.

Bisri, Ilhami, Sistem Hukum Indonesia Prinsip-Prinsip dan Implementasi Hukum di Indonesia, Jakarta: Rajawali Pers, 2010.

Bruggink, J.J. H, Refleksi tentang Hukum, Diterjemahkan oleh Arief Sidharta dari buku asli yang berjudul "Rechtsreflecties", Bandung: Citra Aditya Bakti, 1999.

Departemen Agama RI, Al-Qur'an dan Terjemahnya, Jakarta: Cahaya Qur'an, 2006. Djazuli, A, Kaidah-kaidah Fikih: Kaidah-kaidah Hukum Is Menyelesaikan Masalah-Masalah yang Praktis, Jakarta: Kenca Fuady, Munir, Profesi Mulia (Etika Profesi Hukum bagi Hakim, Jaksa, Advokat, Notaris, Kurator, dan Pengurus), Bandung: PT. Citra Aditya Bakti, 2005.

Hadi, P. Hardono, Hakikat dan Muatan Filsafat Pancasila, Yogyakarta: Kanisius, 1994.

Hasan Bisri, Cik, Pilar-Pilar Penelitian Hukum Islam dan Pranata Sosial, Jakarta: PT. RajaGrafindo Persada, 2004.

Hs, Fachruddin, Membentuk Moral (Bimbingan Al-Qur'an), Jakarta: Bina Aksara, 1985.

Kamil, Ahmad dan. Fauzan, M., Kaidah-Kaidah Hukum Yurisprudensi, Jakarta: Kencana, 2008.

Kansil, C.S.T, Pengantar Ilmu Hukum dan Tata Hukum Indonesia, Jakarta: PN BalaiPustaka, 1984.

Kansil, C.S.T, dan Kansil, Christine S.T., Pokok-Pokok Etika Profesi Hukum, Jakarta: Pradnya Paramita, 2006. 
Kanter, E.Y, Etika Profesi Hukum: Sebuah Pendekatan Sosio-Religius, Jakarta: Storia Grafika, 2001.

Kusnadi, Didi, Bantuan Hukum dalam Islam Profesi Kepengacaraan dalam Islam dan Prakteknya, Bandung: Pustaka Setia, 2012.

Kusumaatmadja, Mochtar, dan Sidartha, B. Arif, Pengantar Ilmu Hukum Suatu Pengenalan Pertama Ruang Lingkup Berlakunya Ilmu Hukum (Buku I), Bandung: Alumni, 2000.

Lev, Daniel S, Hukum dan Politik di Indonesia, Jakarta: LP3ES, 1990.

Loudoe, John Z., Menemukan Hukum melalui Tafsir dan Fakta, Jakarta: PT. Bina Aksara, 1985.

Lubis, K. Suhrawardi, Etika Profesi Hukum, Jakarta: Sinar Grafika, 2008.

Mahali, A. Mudjab, Asbabun Nuzul: Studi Pendalaman Al-Qur'an, Jakarta: PT. RajaGrafindo Persada, 2002.

Manan Abdul, Etika Hakim dalam Penyelenggaraan Peradilan (Suatu kajian dalam Sistem Peradilan Islam), Jakarta: Kencana, 2007.

Mardani, Ayat-ayat Tematik Hukum Islam, Jakarta: Rajawali Pers, 2011. Marwan, M, dan P, Jimmy, Kamus Hukum Dictionary of Law Com Surabaya: Reality Publisher, 2009.

Marzuki, Peter Mahmud, Penelitian Hukum, Jakarta: Kencana, 2010.

Mertokusumo, Sudikno, Penemuan Hukum, Yogyakarta: Universitas Atma Jaya, 2010.

Muhammad, Abdulkadir, Etika Profesi Hukum, Bandung: Citra Aditya Bakti, 2006. Muhammad, Rusdji Ali, Hak Asasi Manusia dalam Perspektif Syari'at Islam Mengenal Jati Diri Manusia, Jakarta: Mihrab, 2004.

Musbikin, Imam, Qawa'id al-fiqhiyah, Jakarta: PT. RajaGrafindo Persada, 2001. Nuh, Muhammad, Etika Profesi Hukum, Bandung: Pustaka Setia, 2011.

Pelu, Ibnu Elmi A.S., dkk, Reaktualisasi Cita Hukum dalam Pembangunan Hukum, Malang: in-TRANS, 2007. 
Pieris, John, Etika dan Penegakan Kode Etik Profesi Hukum (Advokat), Jakarta: Badan Pembinaan Hukum Nasional Departemen Hukum dan Hak Asasi Manusia RI, 2008.

Poedjawiyatna, Etika Filsafat Tingkah Laku, Jakarta: Rineka Cipta, 1990.

Poespoprodjo, W, Filsafat Moral Kesusilaan dalam Teori dan Praktek, Bandung: Pustaka Grafika, 1999.

Puspa, Yan Pramadya, Kamus Hukum Edisi Lengkap Bahasa Belanda Indonesia Inggris, Semarang: Aneka Ilmu, 1977.

Quthb, Sayyid, Tafsir Fi-Zhilalil Qur'an: Di Bawah Naungan Al-Qur'an (Jilid 5: Juz 5 dan 6), Diterjemahkan oleh Aunur Rafiq Shaleh Tamhid dan Khoirul Halim dari buku asli yang berjudul "Fi-Zhilalil Qur'an", Jakarta: Robbani Press, 2002.

Rahardjo, Satjipto, Hukum dan Masyarakat, Bandung: Angkasa, 1980. Rahardjo, Satjipto, Ilmu Hukum, Bandung: Citra Aditya Bakti, 2000. Rahman, Taupik, Hadis-Hadis Hukum, Bandung: Pustaka Setia, 2000.

Rambe, Ropaun, Teknik Praktek Advokat, Jakarta: PT. Gramedia Widiasarana Indonesia, 2001.

Rasjidi, Lili, dan Rasjidi, Ira Thania, Pengantar Filsafat Hukum, Bandung: Mandar Maju, 2002.

Rasjidi, Lili, dan Putra, I.B. Wyasa, Hukum sebagai Suatu Sistem, Bandung: Mandar Maju, 2003.

Schacht, Joseph, Pengantar Hukum Islam, Diterjemahkan oleh Joko Supomo dari buku asli yang berjudul "an Introduction to Islamic Law", Yogyakarta: Imperium, 2012.

Shidarta, Moralitas Profesi Hukum Suatu Tawaran Kerangka Berpikir, Bandung: Refika Aditama, 2009.

Shihab, M. Quraish, Tafsir Al-Mishbah: Pesan, Kesan dan Keserasian AlQur'an (Volume 2: Surah Ali Imran Surah An-Nisa>), Jakarta: Lentera Hati, 2002.

Shihab, Umar, Kontekstualitas Al-Qur'an: Kajian Tematik Atas Ayat-ayat Hukum dalam Al-Qur'an, Jakarta: Pernamadani, 2008. 
Simorangkir, J.C.T, dkk, Kamus Hukum, Jakarta: Sinar Grafika, 2004. Sinaga, V. Harlen, Dasar-Dasar Profesi Advokat, Jakarta: Erlangga, 2011.

Soekanto, Soerjono, Faktor-Faktor yang Mempengaruhi Penegakan Hukum, Jakarta: Rajawali Pers, 2012.

Soekanto, Soerjono, dan Mamudji, Sri, Penelitian Normatif, Jakarta: Rajawali Pers, 2010.

Subekti, R., dan Tjitrosoedibio, R., Kamus Hukum, Jakarta: Pradnya Paramita, 2005. Suma, Moh. Amin, Pengantar Tafsir Ahkam, Jakarta: PT. RajaGrafindo Persada,2002.

Sumaryono, E., Etika Profesi Hukum Norma-norma $\stackrel{n}{n}$ Bagi Penegak Hukum, Yogyakarta: Kanisius, 1995.

Sunggono, Bambang, Metodologi Penelitian Hukum, Jakarta: Rajawali Pers, 2012

Sunoto, Mengenal Filsafat Pancasila Pendekatan Melalui: Etika Pancasila, Yogyakarta: PT. Hanindita, 1985.

Supriadi, Etika dan Tanggung Jawab Profesi Hukum di Indonesia, Jakarta: Sinar Grafika, 2008.

Suseno, Frans Magnis, Etika Dasar Masalah-masalah Pokok Filsafat Moral, Jakarta: Kanisius, 1987.

Syaltut, Mahmud, Tafsir al-Quranul Karim (Pendekatan Syaltut dala Esensi alQuran), Diterjemahkan oleh Herry Noer Ali dari buk berjudul "Tafsir alQuranul Karim”, Bandung: CV. Diponegoro, 1990.

Tanya, Bernard L, dkk, Teori Hukum Strategi Tertib Manusia Lintas Ruang dan Generasi, Yogyakarta: Genta Publishing, 2010.

Tim, Kamus Lengkap Arab-Indonesia, Surabaya: Kashiko, 2000.

Tim Penyusun Kamus Pusat Bahasa, Kamus Besar Bahasa Indonesia, Jakarta: Balai Pustaka, 2005

Tim Penyusun, Pedoman Penulisan Skripsi Sekolah Tinggi Agama Islam Negeri Palangka Raya, Palangka Raya: STAIN Palangka Raya Press, 2007

Utsman, Sabian, Dasar-dasar Sosiologi Hukum Makna Dialog antara Hukum \& Masyarakat, Yogyakarta: Pustaka Pelajar, 2010. 
Utsman, Sabian, Living Law: Transformasi Hukum Saka dalam Identitas Hukum Nasional, Yogyakarta: Pustaka Pelajar, 2011.

Waluyo, Bambang, Penelitian Hukum dalam Praktek, Jakarta: Sinar Grafika, 2008.

Wignjosoebroto, Soetandyo, Dari Hukum Kolonial ke Hukum Nasional: Suatu Kajian tentang Dinamika Sosial-Politik dalam Perkembangan Hukum selama Satu Setengah Abad di Indonesia (1840-1990), Jakarta: PT. RajaGrafindo Persada, 1995.

Yasid, Abu, Aspek-aspek Penelitian Hukum: Hukum Islam-Hukum Barat, Yogyakarta: Pustaka Pelajar, 2010.

Ya'qub, Hamzah, Etika Islam Pembinaan Akhlaqulkarimah (Suatu Pengantar), Bandung: CV. Diponegoro, 1996.

Zubair, Ahmad Charris, Kuliah Etika, Jakarta: Rajawali Pers, 1990.

\section{Peraturan Perundang-Undang}

KUHPer. (Kitab Undang-Undang Hukum Perdata) KUHP (Kitab UndangUndang Hukum Pidana) KUHAP (Kitab Undang-Undang Hukum Acara Pidana), Jakarta: Pustaka Yustisia, 2010.

Undang-Undang RI No. 18 Tahun 2003 tentang Advokat, Surabaya: Karya Anda, 2003.

Undang-Undang Nomor 39 Tahun 1999 tentang Hak Asasi Manusia. Kode Etik Advokat Indonesia Tahun 2002.

\section{Internet}

http://lib.uin-malang.ac.id/thesis/fullchapter/02210043-asna-rohmaniyati.ps

http://lib.uin-malang.ac.id/thesis/introduction/06210059-indah-wati.ps

http://lib.uin-malang.ac.id/thesis/chapter_ii/06210059-indah-wati.ps

http://lib.uin-malang.ac.id/thesis/fullchapter/06210041-nanang-syari-q.ps 